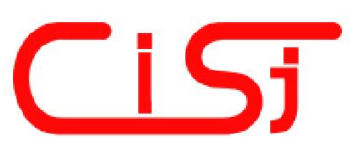

\title{
SIMULATION MODELING OF FUZZY LOGIC CONTROLLER FOR AIRCRAFT ENGINES
}

\author{
Marcin Pasieka ${ }^{1)}$, Norbert Grzesik ${ }^{2)}$, Konrad Kuźma ${ }^{2)}$ \\ ${ }^{1)}$ ul. Smętowska 16 85-552 Bydgoszcz, Poland, pasmar1@gazeta.pl \\ 2) Polish Air Force Academy, \\ Dywizjonu 303 Nu. 35, 08-521 Dęblin, Poland, norbertgrzesik@op.pl, k.kuzma@wsosp.pl
}

\begin{abstract}
This article described project of fuzzy logic controller witch control the scope of opening cowl flaps in Piper Seneca $\mathrm{V}$ engines. This allows to maintain optimum engine temperature by varying the amount of air flow through the engine compartment. The main task of controller is to reduce pilot workload during the entire flight, as well as to maintain optimum engine operating parameters in order to increase its service life. The designed fuzzy controller generates a cowl flaps control signal according to the three most important input parameters: Cylinder Head Temperature (CHT), Vertical Speed Indicator (VSI), Manifold Pressure (MP). The project uses Matlab and Fuzzy Logic Toolbox software. The authors presented the performance of the system based on twenty samples for research, which simulate position flaps. This articles presented also control surfaces, due to which it is possible to analyze controller performance. At the end showed the simulation process in the Simulink software package with the preset input values. Copyright $(\mathcal{C}$ Research Institute for Intelligent Computer Systems, 2016. All rights reserved.
\end{abstract}

Keywords: fuzzy controller, cowl flaps, Piper Seneca V, fuzzy logic.

\section{INTRODUCTION}

Piloting the aircraft is an activity that requires extensive knowledge, skills, and high focus to techniques fly an airplane, monitoring flight data and operation of the motor, procedures and communication with the Air Traffic Control (ATC) and passing a large number of exams for pilot license. All this is in order to maximize the safety of operations $[3,7]$. Therefore, in order to reduce the workload of the pilot introduces more and more automated systems that have relieve the pilot and allow to focus all attention on other more important tasks [6]. This is particularly important in the singlepilot operations, where the amount of information that goes to the pilot and must be processed is very large and the possibility of error is large.

Hence a preliminary draft Cowl Flaps fuzzy controller for the Piper Seneca V, which main task is to reduce pilot workload during the entire flight, as well as to maintain optimum engine operating parameters in order to increase its service life. For this purpose the parameters of the motor and flight are used. The controller is based on fuzzy logic which is successfully used in many other technical branches [4],[5][10],[16]-[20] as well as nontechnical [11]-[14].

\section{GENERAL INFORMATION}

The proper work of the controller we needs general information about the aircraft, engine and current Cowl flaps control, ATC procedures and fly technics. This information provides an overall view of how the controller should work.

\subsection{AIRCRAFT}

Piper Seneca V is a light, twin-engine passenger plane manufactured by PIPER AIRCFAFT in Florida in United States of America. Designed for the transport of up to 6 people with one man crew. Is approved for visual flight rules, night visual flight rules, instrument flight rules and icing conditions. It is equipped with a glass cockpit based on Avidyne Flight Max with a Maximal Take Off Mass $2155 \mathrm{~kg}$ and Cruise Speed $200 \mathrm{kts}$. It is used mainly as the medium range business airplane and training aircraft. It does not have a pressurized cabin. 


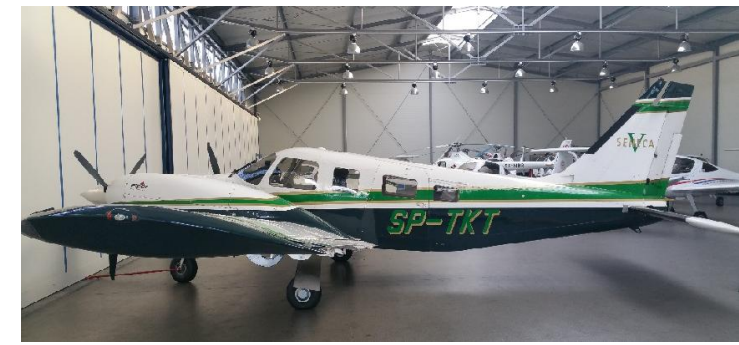

Fig. 1 - Piper Seneca V

\subsection{Engines}

The airplane is equipped with two air-cooled engines one TSIO-360-RB and the second LTSIO$360-\mathrm{RB}$ is 6-cylinder piston engine with a turbo compressor with a power of $220 \mathrm{HP}$ at $2600 \mathrm{RPM}$ to Continentals MOTORS built in Alabama in the United States [2]. It uses 100LL fuel (AVGAS).

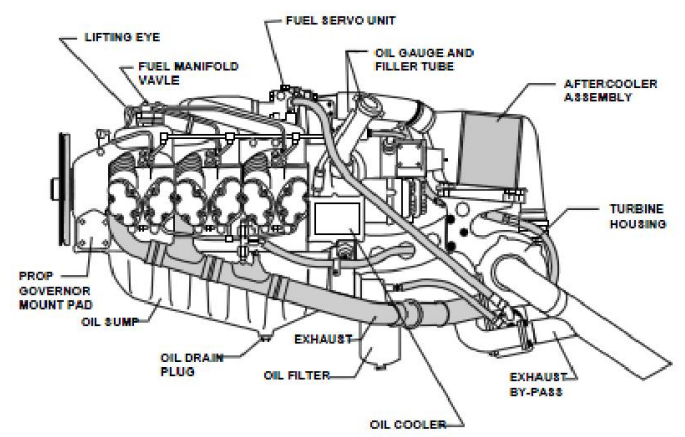

Fig.2 - Engine TSIO-360-RB www.continentalmotors.com

\subsection{CURRENT CONTROL COWL FLAP}

In the standard airplane model, control cowl flaps, are carried out by two mechanical lever located under the instrument panel, allowing pilot to set it in three different positions: (1) open, (2) semiopen, (3) closed, depends on (according to the manufacturer's instructions) phase of flight, engine work parameters and performed maneuvers.

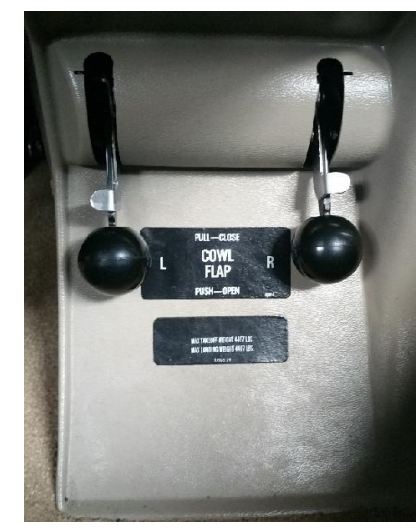

Fig.3 - Cowl Flaps Levers

\section{MECHANISM OF CONTROL COLW FLAP}

\subsection{INPUTS SIGNALS}

Correct operation of the controller cowl flaps requires three input signals that are used to determine the phase of flight and engine parameters:

- Cylinder Head Temperature (CHT) is expressed in Fahrenheit degrees and is displayed on the MultiFunction Display (MFD) - the display range is $100 \div 600$ Fahrenheit degrees. This is the main parameter determining the actual temperature of the cylinder heads.

- Vertical Speed Indicator (VSI) is one of the basic pilot devices, which is used to indicate aircraft vertical speed. In Seneca V aircraft, the instrument is calibrated in the range of -2000 to 2000 feet per minute.

- Manifold Pressure - this is the absolute pressure in the manifold of the engine control lever in the aircraft cockpit. The maximum value cannot exceed 40 inches of mercury.

\subsection{OUTPUT SIGNAL}

The controller output signal is the position of the cowl flap. In the first controller, we have 3 positions in the second 6 positions of the cowl flap. The increase was due to the position regulator optimization for its better functioning.

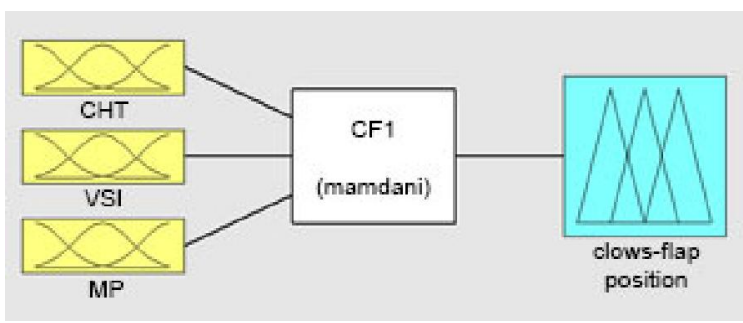

Fig.4 - Scheme input and output signals

\section{CONTROLLER NO 1}

It was designed using fuzzy logic [8][9][15] with Matlab fuzzy logic toolbox and has three input signals, wherein each has three sub-ranges and one output signal from the three positions cowl flaps. [1] Controller work is based on twenty-seven inference rules.

\subsection{INPUTS SIGNAL - SUB-RANGES}

The total temperature range is from 0 to 700 Fahrenheit degrees and distinguished three subranges:

- Cool $0 \div 180 / 200$ Fahrenheit degrees (type of 
function: $\mathrm{zmf}$ );

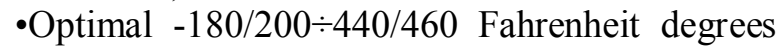
(type of function: trapmf);

- Hot 440/460 $\div 700$ Fahrenheit degrees (type of function: smf).

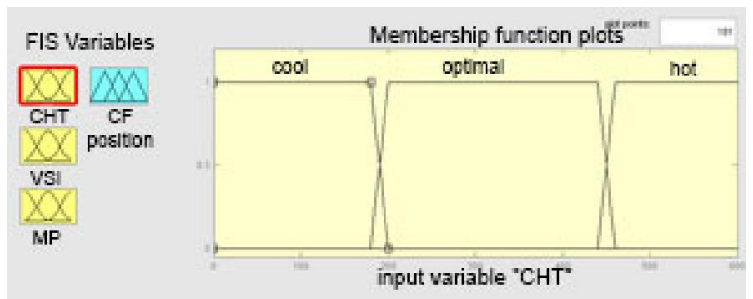

Fig.5 - Input signal characteristic - CHT

The total vertical speed range is from -5000 to 5000 feet per minute, and distinguish three subranges:

- Descent $-5000 \div-1000 /-200$ feet per minute (type of function: $\mathrm{zmf}$ );

- Level flight $-1000 /-200 \div 200 / 1000$ feet per minute (type of function: trapmf);

-Climb 200/1000 $\div 5000$ feet per minute type of function: smf).

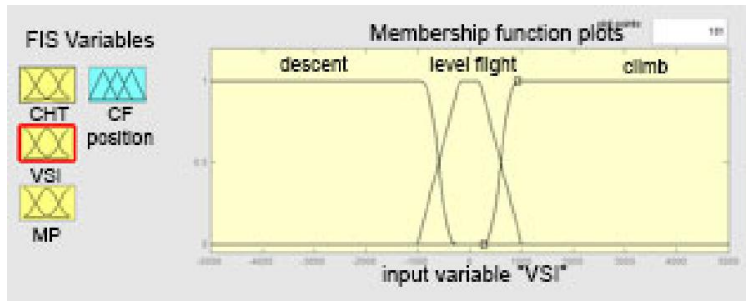

Fig.6 - Input signal characteristic - VSI

The total Manifold Pressure range from 0 to 40 inches of mercury and distinguish three sub-ranges:

- Idle $0 \div 16 / 19$ inches of mercury (type of function: $\mathrm{zmf}$ );

- Cruise $16 / 19 \div 25 / 28$ inches of mercury (type of function: trapmf);

- Take-off $25 / 28 \div 40$ inches of mercury (type of function: smf).

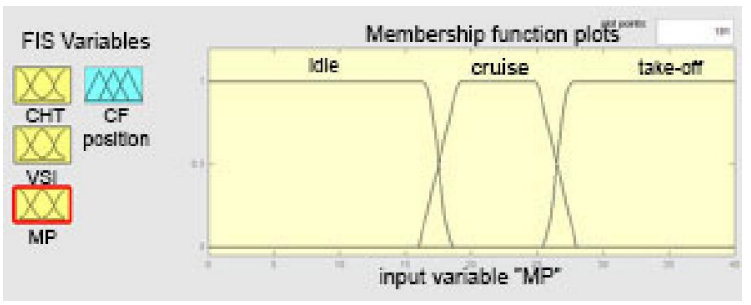

Fig.7 - Input signal characteristic - MP

\subsection{OUTPUT SIGNAL- SUB-RANGES}

At the output, three are three membership functions which describes opening or closing the flaps signals. All functions are triangular. Value of 0 means that flaps are open, value of 1 means that flaps are closed.

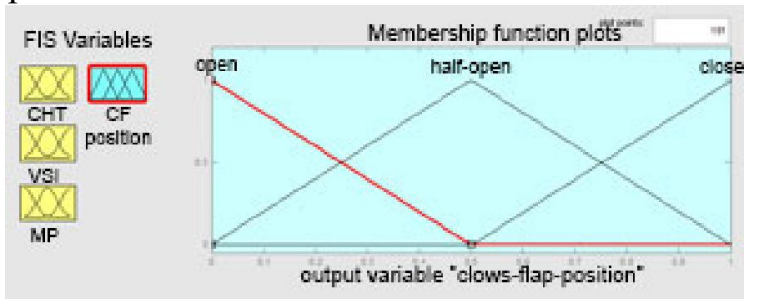

Fig.8 - Output signal characteristic - Flaps position

\subsection{CALCULATIONS FOR 20 SAMPLES}

To verify the first controller proper work 20 data samples were selected. The controller calculations are presented in table 1 .

Table 1. Calculation samples for controller NO 1

\begin{tabular}{|c|c|c|c|c|}
\hline & \multicolumn{3}{|c|}{ Input parameters } & \multirow{2}{*}{$\begin{array}{c}\text { Flaps } \\
\text { position }\end{array}$} \\
\cline { 2 - 4 } & $\boldsymbol{C H T}$ & $\boldsymbol{V S I}$ & $\boldsymbol{M P}$ & 0,163 \\
\hline 1. & 350 & 0 & 20 & 0,181 \\
\hline 2. & 400 & 500 & 25 & 0,438 \\
\hline 3. & 450 & 500 & 17 & 0,181 \\
\hline 4. & 500 & 500 & 17 & 0,181 \\
\hline 5. & 500 & 500 & 27 & 0,819 \\
\hline 6. & 150 & -500 & 13 & 0,837 \\
\hline 7. & 150 & -1500 & 13 & 0,163 \\
\hline 8. & 610 & -1500 & 35 & 0,5 \\
\hline 9. & 330 & -1500 & 24 & 0,163 \\
\hline 10. & 330 & 1500 & 24 & 0,822 \\
\hline 11. & 100 & 200 & 18 & 0,837 \\
\hline 12. & 150 & 100 & 19 & 0,166 \\
\hline 13. & 400 & 800 & 20 & 0,163 \\
\hline 14. & 600 & -900 & 20 & 0,837 \\
\hline 15. & 150 & -1500 & 13 & 0,163 \\
\hline 16. & 250 & 2500 & 13 & 0,163 \\
\hline 17. & 250 & -2500 & 40 & 0,163 \\
\hline 18. & 300 & -1100 & 35 & 0,163 \\
\hline 19. & 375 & 1400 & 33 & 0,163 \\
\hline 20. & 450 & 1400 & 23 & \\
\hline & & & & \\
\hline
\end{tabular}

\subsection{FIRST OBSERVATIONS}

When analyzing the results and generated control surface can be observed that: (1) controller work is leaped, (2) regardless of control surface and input parameters the regulator does not reach a value of 0 and 1, (3) the ,SOM" defuzzification method supports receiving output integer values, (4) partly flat parts of control surfaces, (5) the controller requires optimization. 


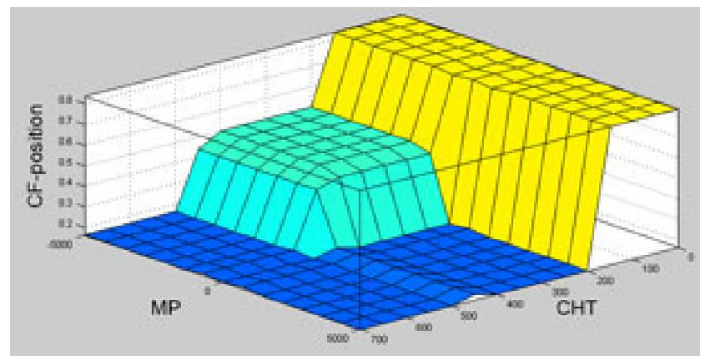

Fig.9 - Control Surface MP and CHT Controller NO 1

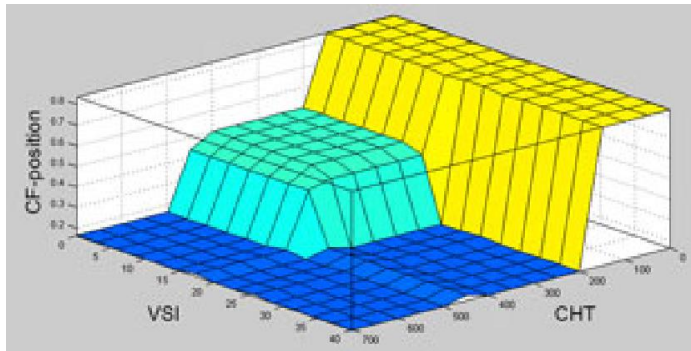

Fig.10 - Control Surface VSI and CHT Controller NO 1

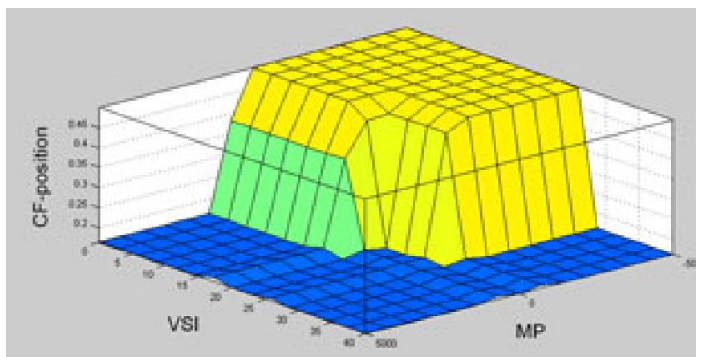

Fig.11 - Control Surface MP and VSI Controller NO 1

\section{CONTROLLER NO 2}

This project is an optimized version of the controller No. 1, however, it was built from scratch, input signal ranges were changed, also output signal amount of membership functions were increased. All changes mentioned above lead to improve controller accuracy and had also been created using the Matlab fuzzy logic toolbox. Controller used one hundred twenty five inference rules.

\subsection{INPUTS SIGNAL - SUB-RANGES}

The total temperature range is from 0 to 700 Fahrenheit degrees and distinguished five subranges:

- Cold 100/100 $\div 200 / 240$ Fahrenheit degrees (type of function: trapmf);

- Cool 200/240 280/300 Fahrenheit degrees (type of function: trapmf);

- Optimum 280/300 $\div 400 / 420$ Fahrenheit degrees (type of function: trapmf);

- Hot 400/420 460/480 Fahrenheit degrees (type of function: trapmf);

- Overheat 460/480 $\div 600 / 600$ Fahrenheit degrees (type of function: trapmf).

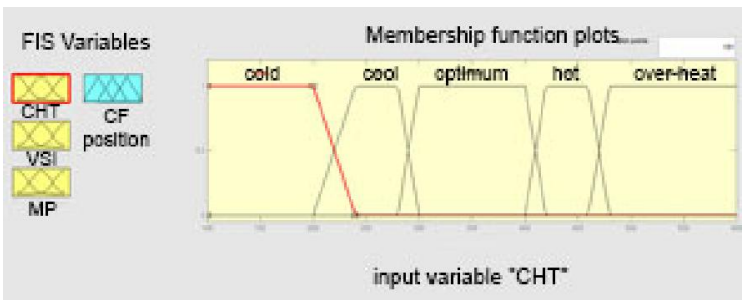

Fig.11 - Input signal characteristic - CHT

The total vertical speed range is from -2000 to 2000 feet per minute and distinguish five subranges:

- Fast Descent -2000/-2000 $\div-1100 /-900$ feet per minute (type of function: trapmf);

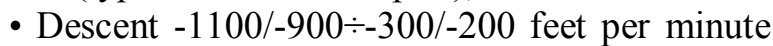
(type of function: trapmf);

- Flight Level $-300 /-200 \div 200 / 300$ feet per minute (type of function: trapmf);

- Climb 200/300 $\div 900 / 1100$ feet per minute (type of function: trapmf);

- Fast Climb 900/1100 $\div 2000 / 2000$ feet per minute (type of function: trapmf).

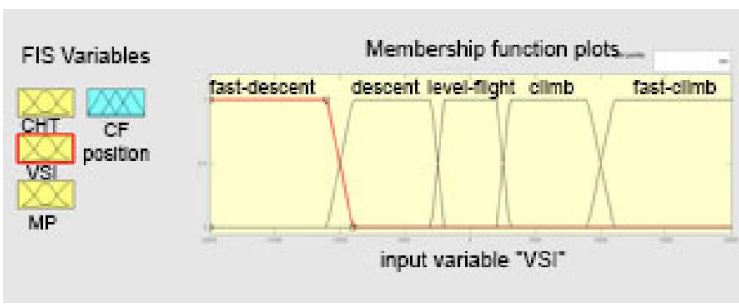

Fig.12 - Input signal characteristic - VSI

The total Manifold Pressure range is from 0 to 40 inches of mercury and distinguish five sub-ranges:

- Idle $0 / 0 \div 10 / 14$ inches of mercury (type of function: trapmf);

- Descent $10 / 14 \div 18 / 20$ inches of mercury (type of function: trapmf);

- Cruise 18/20 $\div 25 / 27$ inches of mercury (type of function: trapmf);

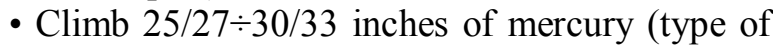
function: trapmf);

- Take-off $30 / 33 \div 40 / 40$ inches of mercury (type of function: trapmf).

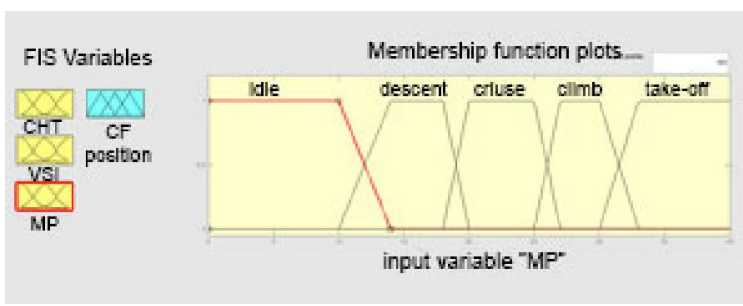

Fig.13 - Input signal characteristic - MP 


\subsection{CALCULATIONS FOR 20 SAMPLES}

The samples were precise selected to display all controller work range and its reaction for input data.

Table 2. Calculation samples for controller NO 2

\begin{tabular}{|l|c|c|c|c|}
\hline & \multicolumn{3}{|c|}{ Inputs parameters } & \multirow{2}{*}{$\begin{array}{c}\text { Flaps } \\
\text { position }\end{array}$} \\
\cline { 2 - 4 } & $\boldsymbol{C H T}$ & $\boldsymbol{V S I}$ & $\boldsymbol{M P}$ & 0,2 \\
\hline 1. & 350 & 0 & 20 & 0,2 \\
\hline 2. & 400 & 500 & 25 & 0,4 \\
\hline 3. & 450 & 500 & 17 & 0,0633 \\
\hline 4. & 500 & 500 & 17 & 0,0633 \\
\hline 5. & 500 & 500 & 27 & 0,933 \\
\hline 6. & 150 & -500 & 13 & 0,933 \\
\hline 7. & 150 & -1500 & 13 & 0,0633 \\
\hline 8. & 610 & -1500 & 35 & 0,6 \\
\hline 9. & 330 & -1500 & 24 & 0,2 \\
\hline 10. & 330 & 1500 & 24 & 0,8 \\
\hline 11. & 100 & 200 & 18 & 0,8 \\
\hline 12. & 150 & 100 & 19 & 0,2 \\
\hline 13. & 400 & 800 & 20 & 0,0633 \\
\hline 14. & 600 & -900 & 20 & 0.933 \\
\hline 15. & 150 & -1500 & 13 & 0,658 \\
\hline 16. & 250 & $2500(2000)$ & 13 & 0,4 \\
\hline 17. & 250 & -2500 & 40 & 0,2 \\
\hline 18. & 300 & -1100 & 35 & 0,0633 \\
\hline 19. & 375 & 1400 & 33 & 0,2 \\
\hline 20. & 450 & 1400 & 23 & \\
\hline & & & & \\
\hline
\end{tabular}

\section{COMPARISON CONTROLLERS}

In the table below, controllers output changing values comparison is presented. Again in both cases, controllers have reached neither zero nor one value, which indicates the need for further optimization of the controller.

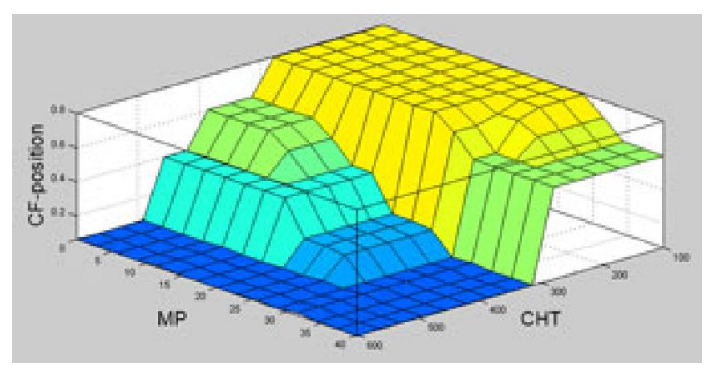

Fig.14 - Control Surface MP and CHT Controller NO 2

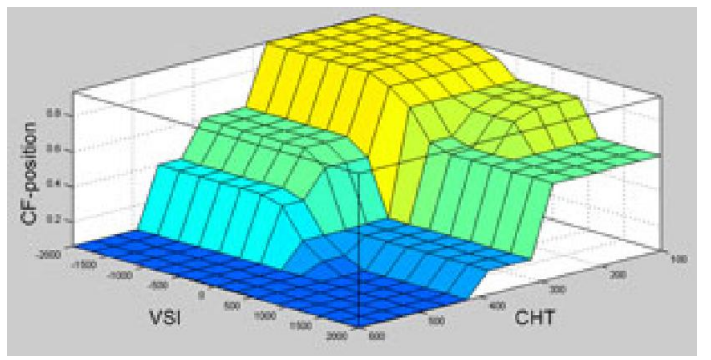

Fig.15 - Control Surface VSI and CHT Controller NO 2

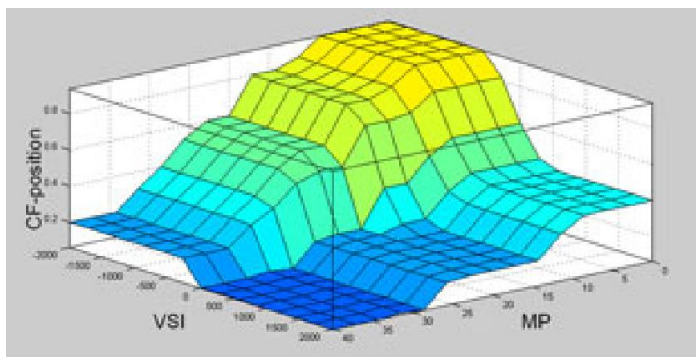

Fig.16 - Control Surface VSI and MP Controller NO 2

Table 3. Controllers output changing values comparison

\begin{tabular}{|l|c|c|c|c|c|}
\hline & \multicolumn{3}{|c|}{ Inputs parameters } & $\begin{array}{c}\text { Position } \\
\text { flaps in } \\
\text { Controller } \\
\text { I }\end{array}$ & $\begin{array}{c}\text { Position } \\
\text { flaps in } \\
\text { Controller } \\
\text { II }\end{array}$ \\
\cline { 2 - 6 } & $\boldsymbol{C H T}$ & $\boldsymbol{V S I}$ & $\boldsymbol{M P}$ & 0,163 & 0,2 \\
\hline 1. & 350 & 0 & 20 & 0,181 & 0,2 \\
\hline 2. & 400 & 500 & 25 & 0,181 & 0,4 \\
\hline 3. & 450 & 500 & 17 & 0,438 & 0,0633 \\
\hline 4. & 500 & 500 & 17 & 0,181 & 0,0633 \\
\hline 5. & 500 & 500 & 27 & 0,181 & 0,933 \\
\hline 6. & 150 & -500 & 13 & 0,819 & 0,933 \\
\hline 7. & 150 & -1500 & 13 & 0,837 & 0,633 \\
\hline 8. & 610 & -1500 & 35 & 0,163 & 0,6 \\
\hline 9. & 330 & -1500 & 24 & 0,5 & 0,2 \\
\hline 10. & 330 & 1500 & 24 & 0,163 & 0,8 \\
\hline 11. & 100 & 200 & 18 & 0,822 & 0,8 \\
\hline 12. & 150 & 100 & 19 & 0,837 & 0,8 \\
\hline 13. & 400 & 800 & 20 & 0,166 & 0,2 \\
\hline 14. & 600 & -900 & 20 & 0,163 & 0,0633 \\
\hline 15. & 150 & -1500 & 13 & 0,837 & 0.933 \\
\hline 16. & 250 & 2500 & 13 & 0,163 & 0,658 \\
\hline 17. & 250 & -2500 & 40 & 0,163 & 0,4 \\
\hline 18. & 300 & -1100 & 35 & 0,163 & 0,2 \\
\hline 19. & 375 & 1400 & 33 & 0,163 & 0,0633 \\
\hline 20. & 450 & 1400 & 23 & 0,163 & 0,2 \\
\hline
\end{tabular}

\section{SIMULATION}

In order to verify the operation of the fuzzy logic controller, it is necessary to conduct an examination in the next Matlab module - Simulink. For this purpose a model of the tested system was developed, which tests the correct operation of the controller with the use of such components as:

- $3 \mathrm{x}$ signal builder - create and generate input signals;

- mux block - combines inputs signals into a single vector output;

- Fuzzy Logic Controller - implements a fuzzy inference system in Simulink;

- Display - show the current (last) value of input;

- 2 x Scope - display signals generated during simulation. 


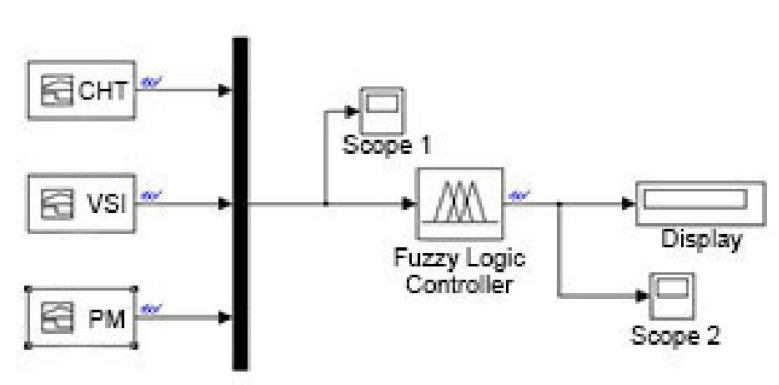

Fig.17 - The scheme of the fuzzy logic controller in the Simulink software

Input waveforms (CHT, VSI, MP), used for the simulation, were set similarly to the values of 20 samples previously analyzed. They are shown in Fig.18.

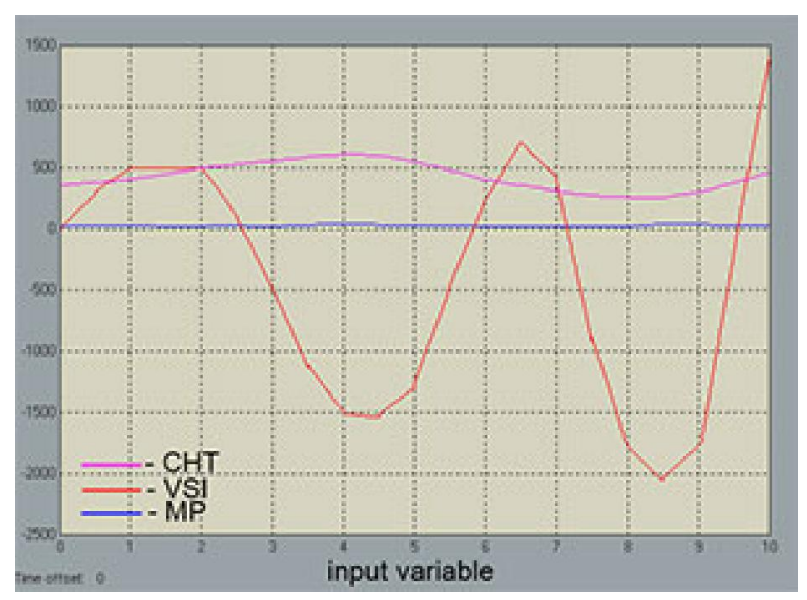

Fig.18 - Input signals (CHT, VSI, MP)

Fig. 19 presents the diagram received from the scope set at the system exit. It shows the position of cowl flaps during 10 seconds of simulation.

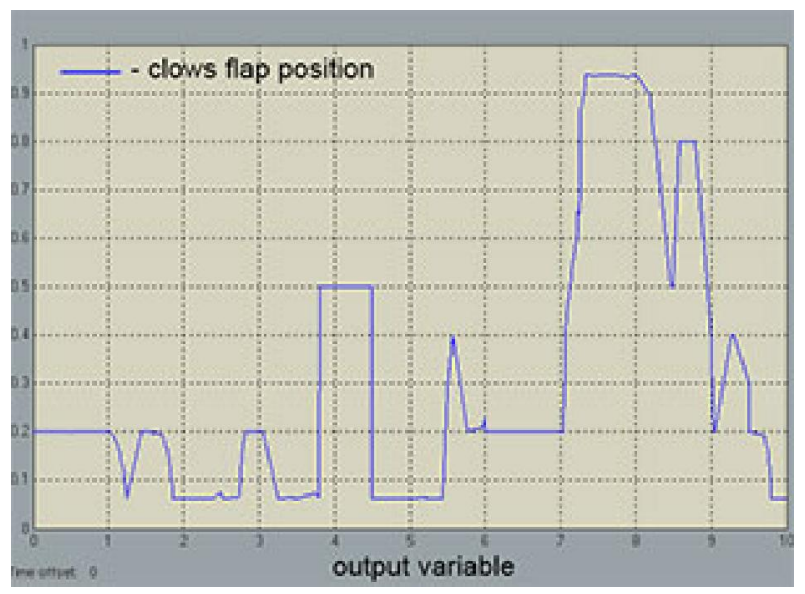

Fig.19 - Output signals (clows flap position)

The simulation confirmed negative phenomena arising in the optimization process: controller have reached neither zero nor one value and work is leaped. Although it can be seen that generally the work of the controller is satisfactory. Cowl flaps are open when the temperature of the cylinder heads and speed of descent are high. On the other hand when the temperature of the cylinder heads and speed of climb are high, cowl flaps are closed. Received results indicate the possibility of using the fuzzy logic controller in the cowl flap system.

\section{CONCLUSIONS}

The optimization phase for designed controller project is necessary to increase its work accuracy. Furthermore, it is important, during designing process, to select appropriate parameters ranges and membership functions amount in the input and output signals. Increasing number of membership functions give an expert more possibilities to adapt the controller to the work task. Unfortunately each additional membership functions generates a greater number of rules, which requires a wider look at the problem.

The fuzzy controller was established primarily based on the official pilot operating handbook and the practical experience while piloting a plane, but the project needs to be extended to analysis of whole available flight situation spectrum. All designed controllers, calculations and results analysis should be treated as an introduction to further problem consideration and the enriched with other input parameters increasing its reliability and accuracy. What is most important, test flights during routine and non-routine situations (firstly in simulatorsvirtually) is indispensable.

\section{REFERENCES}

[1] N. Grzesik, Podstawy Sterowania Rozmytego Projektowanie Rozmytych Systemów Eksperckich w Środowisku Matlab-Simulink, Wyższa Szkoła Oficerska Sił Powietrznych, Dęblin, 2012. (in Polish).

[2] Seneca V, PA-34-220T (1999 kg), SN3449311, 3449323 and up, Pilot's Operating Handbook and FAA approved airplane Flight Manual, FAA, Issue 06, 2017.

[3] M. Jasztal, J. Żurek, H. Tomaszek, Prognozowanie Uszkodzeń Zagrażających Bezpieczeństwu Lotów Statków Powietrznych, Wydawnictwo naukowe ITE, Radom 2008.

[4] A. Azadeh, V. Ebrahimipour, P. Bavar, "A fuzzy inference system for pump failure diagnosis to improve maintenance process: The case of a petrochemical industry," Expert Systems with Applications, Vol. 37, pp.627639, 2010.

[5] A. Sergaki, K. Kalaitzakis, “A fuzzy knowledge based method for maintenance planning in a 
power system," Reliability Engineering and System Safety, Vol. 77, pp. 19-30, 2002.

[6] J. Żurek, N. Grzesik, "Fuzzy expert aircraft onboard control systems assistant," Safety reliability and risk analysis: Beyond the horizon," in ESREL Conference Proceedings, London: Taylor \& Francis Group, 2013, pp. 250-251.

[7] J. Skorupski, M. Wiktorowski, "The model of a pilot competency as a factor influencing the safety of air traffic," Safety and Reliability: Methodology and Applications, Nowakowski et al. (Eds), Taylor \& Francis Group, London, 2015.

[8] L. Zadeh, "Fuzzy Sets," Information and Control, Vol. 8, 1965.

[9] R. Yager, D. Filev, Podstawy Modelowania $i$ Sterowania Rozmytego, WNT, Warszawa, 1995.

[10] M. Pasieka, N. Grzesik, "Project of Piper Seneca V (PA-34-220T) cowl flaps (cf) controller based on fuzzy logic, in Proceedings of the IEEE 8th International Conference on Intelligent Data Acquisition and Advanced Computing Systems: Technology and Applications (IDAACS'2015), Warsaw, Poland, September 24-26, 2015, pp. 203-207.

[11] S. Chaudhari, M. Patil, "Study and review of fuzzy inference systems for decision making and control," American International Journal of Research in Science, Technology, Engineering \& Mathematics, 2014, ISSN (Print): 23283491, ISSN (Online): 2328-3580, ISSN (CDROM): 2328-3629.

[12] P. H. Giang, "Decision making under uncertainty comprising complete ignorance and probability, International Journal of Approximate Reasoning, Vol. 62, pp. 27-45, 2015.

[13] M. Lower, J. Magott, J. Skorupski, “Analiza incydentów lotniczych z zastosowaniem zbiorów rozmytych," Prace naukowe Politechniki Warszawskiej: Transport, Warszawa, 2013.

[14] M. Hadjimichael, "A fuzzy expert system for aviation risk assessment," Expert Systems with Applications, Vol. 36, Issue 3, Part 2, pp. 65126519, 2009.

[15] W. Pedrycz, "Fuzzy multimodels," IEEE Transactions on Fuzzy Systems, Vol. 4, No. 2, pp 139-148, 1996.

[16] M. A. Usta, O. Akyazi, A. S. Akpinar, "Aircraft roll control system using LQR and fuzzy logic controller," Innovations in Intelligent Systems and Applications (INISTA), 2011.

[17] G. N. Vishnu, M. V. Dileep, K. R. Prahalad, "Design of fuzzy logic controller for lateral dynamics control of aircraft by considering the cross-coupling effect of yaw and roll on each other," International Journal of Computer Applications, Vol. 47, No.13, pp. 44-48, 2012.

[18] H-Z. Huang, "Structural reliability analysis using fuzzy sets theory," Maintenance and Reliability, Vol. 4, pp. 284-294, 2012.

[19] L. Jia, L. Edward, "Fuzzy logic controllers for aircraft flight control," Fuzzy Logic and Intelligent Systems International Series in Intelligent Technologies, Vol. 3, pp. 85-124, 1995.

[20] K. Nho, R. K. Agarwal, "Automatic landing system design using fuzzy logic," Journal of Guidance, Control, and Dynamics, Vol. 23, No. 2, pp. 298-304, 2000.

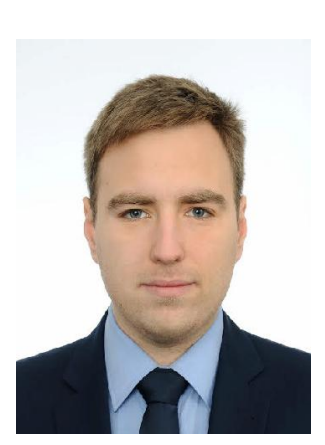

Marcin Paweł Pasieka, born in 1990 in Bydgoszcz, graduated engineering studies at the specialization of pilotage in Polish Airfoce Academy in Dęblin, holder of a Commercial Pilot License, flying instructor, diver, currently employed as a First Officer at Ryanair.

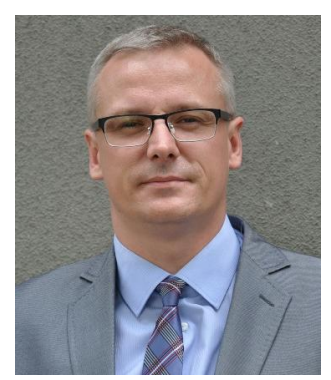

Norbert Paweł Grzesik, born in 1974 in Ostrowiec Swietokrzyski, graduated in Military Uniwersity of Technology in Warsaw, Ph.D, DSc.Eng., aircraft avionics and armament specialist, now Dean of Aviation Faculty, Associate Professor.

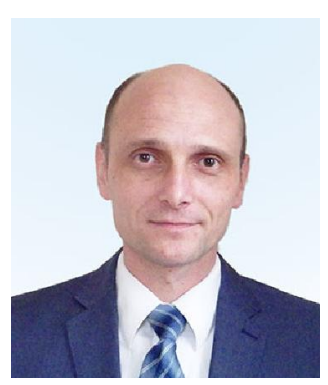

Konrad Adam Kuźma, born in 1977 in Dęblin, graduated in Military Uniwersity of Technology in Warsaw, PhD student, aircraft armament and IT specialist, currently employed as a senior lecturer. 